\title{
ALKALI SILICA REACTION OF BOF AND BFS WASTES COMBINATION IN CEMENT
}

\author{
Ömer Özkan ${ }^{1}$, Mehmet Sarıbıyık ${ }^{2}$ \\ Department of Civil Engineering, Faculty of Technology, Sakarya University, 54187 Sakarya, Turkey \\ E-mails: ${ }^{1}$ omerozkan@sakarya.edu.tr (corresponding author); ${ }^{2}$ mehmets@sakarya.edu.tr \\ Received 10 Mar. 2011; accepted 25 May 2011
}

\begin{abstract}
This study reports the results of an experimental study conducted to determine composite cements manufactured with the combination of Basic Oxygen Furnace (BOF) Slag and Blast Furnace Slag (BFS). The overall objective of this work is to determine whether a combination of BOF slag and BFS can be used as a cementations material to produce Composite Portland Cement (CPC). Three groups of cement are produced for testing. The first group contains BOF slag, the second group contains BFS and the last group contains the mixture of BOF slag and BFS together. Physical properties and Alkali Silica Reaction (ASR) of these groups are also evaluated in this study. Maximum ASR expansion is observed from the sample of CPC created with BOF slag. On the other hand minimum ASR expansion value is located in the sample of CPC created with BFS only.
\end{abstract}

Keywords: alkali silica reaction, steel slag, blast furnace slag, cement.

\section{Introduction}

Concrete production and technology is developed rapidly, and concrete strength is reaching high values. Many researches from all around the world are trying to improve the physical and mechanical properties of the concrete. Industrial wastes are generally considered as a major source of environmental problems in the world. The environmental regulations require waste disposal minimization and force the re-use of waste materials. In addition, European Community (EU) has declared targets to protect the environment and to guarantee a cautious and efficient use of natural resources. Therefore, more efficient solutions such as alternative recovery options need to be investigated. The use of industrial raw materials in the manufacturing of cement is gaining momentum (Pan et al. 2008; Puertas et al. 2010). Nearly 12 million tons of BOF slag is produced in Europe per year. Today about $65 \%$ of the produced BOF slag is used on qualified fields of application such as a bulk material, asphalt aggregate, filling material; cement raw feed, railroad ballast. The remaining $35 \%$ of this slag is still dumped. Therefore, there is a need for further intensive research to decrease this rate as far as possible. From this perspective one can propose the possibility of using solid wastes of iron from steel factories as a raw material in cement and concrete sectors. Various studies (Binici et al. 2007; Shih et al. 2003) have used waste materials in cement production since the fact that the current clinker production is expensive.

BOF slag contains calcium silicates and ferrite with oxides of aluminum, manganese, calcium and magnesium (Reddy et al. 2006). The mineralogical composition of BOF slag changes with its chemical composition. Olivine, merwinite, calcium silicates $\left(\mathrm{C}_{2} \mathrm{~S}, \mathrm{C}_{3} \mathrm{~S}\right), \mathrm{C}_{4} \mathrm{AF}, \mathrm{C}_{2} \mathrm{~F}$,
$\mathrm{CaO}-\mathrm{FeO}-\mathrm{MnO}-\mathrm{MgO}$ in solid solution and free $\mathrm{CaO}$ are common minerals in steel slag (Shih et al. 2004). The presence of $\mathrm{C}_{3} \mathrm{~S}, \mathrm{C}_{2} \mathrm{~S}, \mathrm{C}_{4} \mathrm{AF}$ and $\mathrm{C}_{2} \mathrm{~F}$ confirms that $\mathrm{BOF}$ slag has cementations properties. The free $\mathrm{CaO}$ content increases the basicity of the BOF slag that improves the reactivity of the BOF slag (Shi, Qian 2000). However, high content of free $\mathrm{CaO}$ in $\mathrm{BOF}$ slag shows volume expansion problems (Özkan 2006).

BFS has currently been used in cement and concrete industry. Ground BFS is used as an admixture in concrete or as an additive in the manufacture process of Portland slag cements in countries where large amounts of BFS is available. However some properties of the concrete containing BFS, such as creep, shrinkage, strength to freezethaw resistant are still under discussion, but the use of the BFS in cement and concrete has been proven to have many advantages (Escalante-Garcia et al. 2009; Yüksel et al. 2007). Calcium silicate hydrate (C-S-H) is attained when BFS is added to cement to react with the Portland $(\mathrm{CH})$ which is released by cement hydration. Alkali silica activates this step by increasing the reaction rate.

ASR can cause serious expansion and cracking in concrete, resulting in major structural problems. ASR is caused by a reaction between the hydroxyl ions in the alkaline cement pore solution in the concrete and reactive forms of silica in the aggregate (Ichikawa, Miura 2007). It is well known that both $\mathrm{Ca}(\mathrm{OH})_{2}$ and high $\mathrm{OH}^{-}$ion concentration are necessary for concrete expansion by ASR (Ichikawa 2009). ASR is the most common form of alkali-aggregate reaction (AAR) in concrete; the other one is alkali-carbonate reaction (ACR). ASR and ACR are therefore both subsets of AAR. Various mechanisms have been proposed to explain the dependence of damaging reaction on $\mathrm{Ca}(\mathrm{OH})_{2}$. Chatterji (2005) suggested that 
expansion occurs in concrete when the net amount of material entering are active silica grain $\left(\mathrm{K}^{+}, \mathrm{Na}^{+}, \mathrm{Ca}^{2+}\right.$, $\mathrm{OH}^{-}$) exceeds the amount of material leaving the grain $\left(\mathrm{Si}^{4+}\right)$. The calcium concentration in the pore solution surrounding the grain controls the rate of diffusion of silica away from the reactive site, and at high levels of calcium the migration of silica is prevented leading to expansion. Garcia-Diaz et al. (2006) suggested that $\mathrm{Ca}(\mathrm{OH})_{2}$ acts as a "buffer" to maintain a high concentration of $\mathrm{OH}^{-}$ions in solution, but also provides $\mathrm{Ca}^{2+}$ ions that Exchange for $\mathrm{Na}^{+}$and $\mathrm{K}^{+}$ions in expansive alkalisilica gels to produce no expansive calcium-alkali-silica gels. The $\mathrm{Na}^{+}$and $\mathrm{K}^{+}$ions are thus liberated to produce further damaging reaction (Ichikawa 2009).

In this study ASR of mortars made with cements incorporating BOF slag and BFS in different ratios as a partial replacement of Portland cement clinker are investigated. Specific weight, initial and final setting times and expansion values of composite cements are also investigated.

\section{Materials and procedure}

\subsection{Materials}

Clinker and gypsum used in this study are granted from Lafarge Cement Factory in Turkey. BOF slag and BFS are provided from Ereğli Iron and Steel Company in Turkey. The chemical compositions of these materials are obtained from the X-ray lab and they are tabulated in Table 1. The photographs of granule BOF Slag with a size of $90 \mu \mathrm{m}$ both (a) under-griddle and (b) abovegriddle along with XRD analysis of the BOF slag is given in Fig. 1. Also sand with CEN standard is used to manufacture mortar specimens (TS-EN 196-1 2009).
Table 1. Chemical compositions of BFS and BOF slag, clinker and gypsum (wt. \%)

\begin{tabular}{lcccccc}
\hline \multicolumn{1}{c}{ Materials } & $\mathrm{CaO}$ & $\mathrm{SiO}_{2}$ & $\mathrm{Fe}_{2} \mathrm{O}_{3}$ & $\mathrm{Al}_{2} \mathrm{O}_{3}$ & $\mathrm{MgO}$ & $\mathrm{SO}_{3}$ \\
\hline BFS & 37.80 & 35.10 & 0.70 & 17.54 & 5.50 & 0.70 \\
BOF slag & 58.53 & 10.72 & 15.30 & 1.71 & 4.27 & 0.04 \\
Clinker & 66.11 & 21.57 & 3.17 & 5.09 & 1.74 & 1.35 \\
Gypsum & 32.57 & 0.67 & 0.24 & 0.21 & 2.20 & 46.56 \\
\hline
\end{tabular}

\subsection{Procedure}

BOF Slag and BFS are intermixed with clinker-gypsum to form the binder materials and then four main groups of cement are established on the base of these substitutions. The materials are supplied in granule size as outputs of factory. BFS, BOF Slag and Clinker-Gypsum were ground in a ball mill to a specific surface area of about $2500 \mathrm{~cm}^{2} / \mathrm{g}$. The materials are mixed with each other in the specified amounts and then ground again to achieve specific surface value of $3100-3300 \mathrm{~cm}^{2} / \mathrm{gr}$, thus yielding the cements used in the tests. Composition ratios of the mixtures used in the study is shown in the Table 2. The first group is coded as the reference group and named as $\mathrm{C}$, in the second group, coded as $\mathrm{C}$ 1, Clinker-gypsum mixture is substituted with BOF slag, Clinker-gypsum mixture is replaced with BFS in the third group $\mathrm{C} 2$, and the last group (C3) Clinkergypsum mixture is substituted with the BFS-BOF slag composition that is arranged at a rate of $50 \%$ of BFS and $50 \%$ of BOF slag. All the main groups, except for the reference group $\mathrm{C}$, are further divided into sub-groups and symbolized by suffixes (a, b, c, d) with respect to their changing ratios in compositions; for instance code $\mathrm{C} 3 \mathrm{c}$ symbolize a material that is composed of $40 \%$ clinkerGypsum, 30\% BFS and 30\% BOF slag.
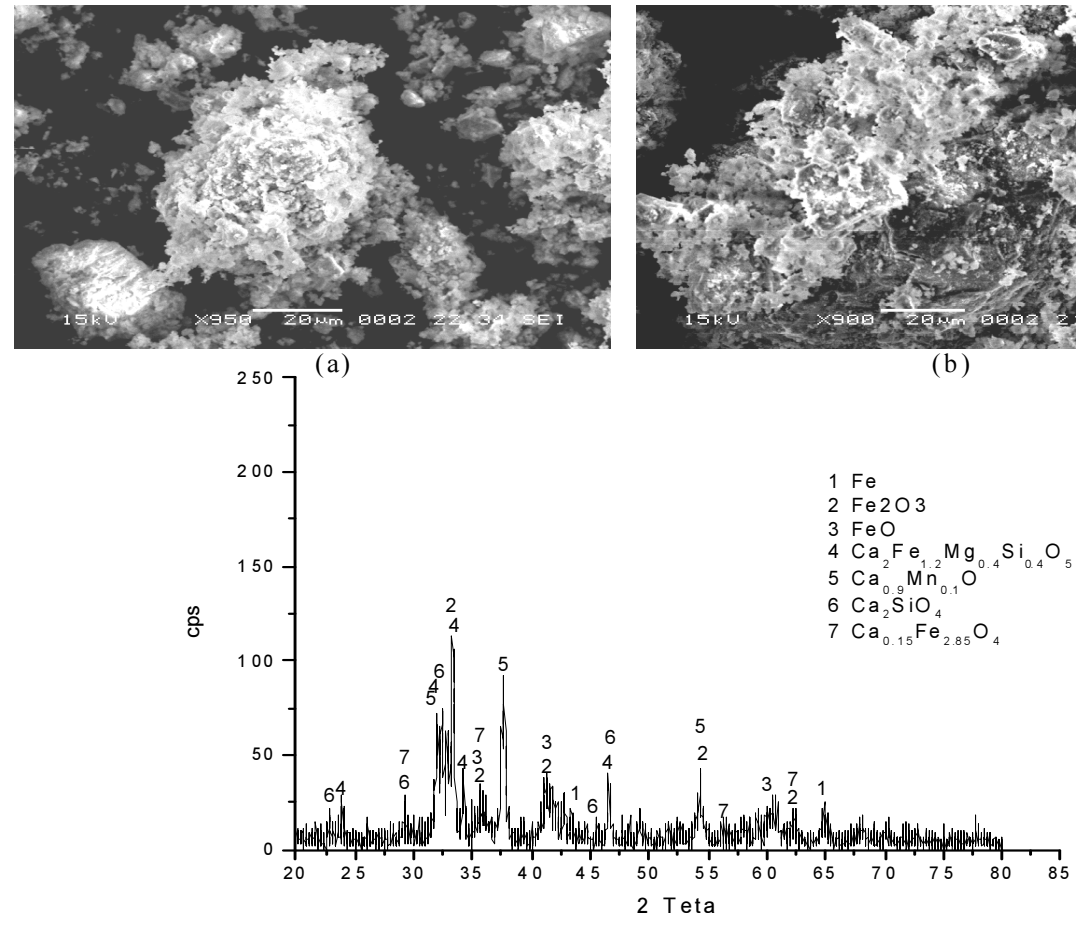

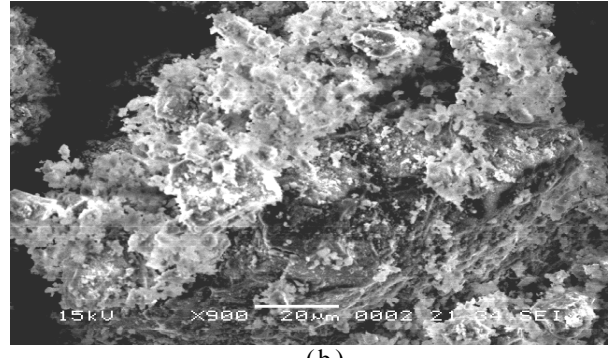

$1 \mathrm{Fe}$

$3 \mathrm{FeO}$

$\mathrm{Mg} \mathrm{Si} \mathrm{O}_{5}$

$\mathrm{Ca} \mathrm{Mn} \mathrm{O}$

$\mathrm{Ca}_{2} \mathrm{SiO}$

$\mathrm{Ca}_{0.15} \mathrm{Fe}_{2.85} \mathrm{O}$

Fig. 1. SEM photographs and XRD analysis of BOF slags 
Table 2. Composition of cement mixtures

\begin{tabular}{|c|c|c|c|c|c|c|}
\hline & Code & Materials & $\begin{array}{c}\text { Clinker } \\
\%\end{array}$ & $\begin{array}{c}\text { Gyps. } \\
\%\end{array}$ & $\begin{array}{c}\text { BFS } \\
\%\end{array}$ & $\begin{array}{c}\text { BOF Slag } \\
\% \\
\end{array}$ \\
\hline & $\mathrm{C}$ & $100 \%$ Clinker-Gypsum & 95 & 5 & 0 & 0 \\
\hline \multirow{4}{*}{$\begin{array}{c}\text { C1 } \\
\text { Series }\end{array}$} & C1a & $80 \%$ Clinker-Gypsum + 20\% BOF Slag & 76 & 4 & 0 & 20 \\
\hline & $\mathrm{C} 1 \mathrm{~b}$ & $60 \%$ Clinker-Gypsum $+40 \%$ BOF Slag & 57 & 3 & 0 & 40 \\
\hline & $\mathrm{C} 1 \mathrm{c}$ & $40 \%$ Clinker-Gypsum $+60 \%$ BOF Slag & 38 & 2 & 0 & 60 \\
\hline & C1d & $20 \%$ Clinker-Gypsum $+80 \%$ BOF Slag & 19 & 1 & 0 & 80 \\
\hline \multirow{4}{*}{$\begin{array}{c}\mathrm{C} 2 \\
\text { Series }\end{array}$} & $\mathrm{C} 2 \mathrm{a}$ & $80 \%$ Clinker-Gypsum $+20 \%$ BFS & 76 & 4 & 20 & 0 \\
\hline & $\mathrm{C} 2 \mathrm{~b}$ & $60 \%$ Clinker-Gypsum $+40 \%$ BFS & 57 & 3 & 40 & 0 \\
\hline & $\mathrm{C} 2 \mathrm{c}$ & $40 \%$ Clinker-Gypsum $+60 \%$ BFS & 38 & 2 & 60 & 0 \\
\hline & $\mathrm{C} 2 \mathrm{~d}$ & $20 \%$ Clinker-Gypsum $+80 \%$ BFS & 19 & 1 & 80 & 0 \\
\hline \multirow{4}{*}{$\begin{array}{c}\text { C3 } \\
\text { Series }\end{array}$} & $\mathrm{C} 3 \mathrm{a}$ & $80 \%$ Clinker-Gypsum $+10 \%$ BFS $+10 \%$ BOF Slag & 76 & 4 & 12 & 8 \\
\hline & $\mathrm{C} 3 \mathrm{~b}$ & $60 \%$ Clinker-Gypsum $+20 \%$ BFS $+20 \%$ BOF Slag & 57 & 3 & 24 & 16 \\
\hline & $\mathrm{C} 3 \mathrm{c}$ & $40 \%$ Clinker-Gypsum $+30 \%$ BFS $+30 \%$ BOF Slag & 38 & 2 & 36 & 24 \\
\hline & $\mathrm{C} 3 \mathrm{~d}$ & $60 \%$ Clinker-Gypsum $+40 \%$ BFS $+40 \%$ BOF Slag & 57 & 3 & 24 & 16 \\
\hline
\end{tabular}

The physical properties of the produced cements, including weight percentages, specific surface values and specific gravities remaining on the sieve sizes of 32 and $90 \mu$, are examined after according to the Turkish Standards (TS-EN 196-6 2000). The beginning and ending times of cement setting and expansion values of cements are also determined according to Turkish Standards (TSEN 196-3 2002).

The ASTM C1260 test is based on the assumption that a very high $\mathrm{pH}$ value of the pore solution initiates the reaction with potentially reactive aggregate. The intention was to create the most severe alkaline conditions as could be expected in the pore solution of mortar bars after hydrolysis, which is the interaction of alkalis and water. ASR test specimens are submerged in a hot and highly alkaline sodium-hydroxide solution $(1 \mathrm{~mol})$. Originally, the test was not designed to consider influences of other components of the mortar mix such as admixtures but solely to determine the reactivity of a given aggregate type (ASTM C-1260 2007). Mortar bars used in this study are of $25 \times 25 \times 290 \mathrm{~mm}$ dimension. Cement, standard rilem sand and tap water with the proportions of 1, 2.25 and 0.47 , respectively.

Specimens were first cured in a room in moulds at $20^{\circ} \mathrm{C}$ for 24 hours. After $24 \mathrm{~h}$ of curing, demoulding took place and the specimens were placed in water at $80{ }^{\circ} \mathrm{C}$ for another $24 \mathrm{~h}$. The reference length was taken and the specimens were then transferred to a solution of $1 \mathrm{~N}$ of $\mathrm{NaOH}$ at $80^{\circ} \mathrm{C}$. Readings were then taken every day for 14 days. At the end of 14 days, the length change was compared to reference specimens. Finally SEM micrographs of mortar bars produced from different cement combinations were taken at 500x and 2000x magnifications. XRD analysis was then performed on samples $C$, $\mathrm{C} 1 \mathrm{~b}, \mathrm{C} 2 \mathrm{~b}$ and $\mathrm{C} 3 \mathrm{~b}$ (Table 3).

\section{Result and discussion}

\subsection{Physical properties of cements}

The physical properties of produced cements are shown in Table 3. Fineness, specific surface and specific gravity are listed.
Table 3. The physical properties of produced cements

\begin{tabular}{lcccc}
\hline Cements & \multicolumn{2}{c}{ Fineness (wt. \%) } & $\begin{array}{c}\text { Specific } \\
\text { surface } \\
\mathrm{cm}^{2} / \mathrm{g}\end{array}$ & $\begin{array}{c}\text { Specific } \\
\text { gravity } \\
\mathrm{g} / \mathrm{cm}^{3}\end{array}$ \\
\hline C & 21.00 & 0.90 & 3330 & 3.12 \\
$\mathrm{C} 1 \mathrm{a}$ & 21.15 & 1.18 & 3214 & 3.06 \\
$\mathrm{C} 1 \mathrm{~b}$ & 22.10 & 1.00 & 3213 & 3.02 \\
$\mathrm{C} 1 \mathrm{c}$ & 22.15 & 1.25 & 3152 & 2.97 \\
$\mathrm{C} 1 \mathrm{~d}$ & 22.10 & 1.20 & 3150 & 2.96 \\
$\mathrm{C} 2 \mathrm{a}$ & 21.20 & 1.10 & 3115 & 3.05 \\
$\mathrm{C} 2 \mathrm{~b}$ & 21.90 & 1.15 & 3108 & 3.01 \\
$\mathrm{C} 2 \mathrm{c}$ & 21.80 & 1.15 & 3090 & 2.95 \\
$\mathrm{C} 2 \mathrm{~d}$ & 21.90 & 1.10 & 3070 & 2.94 \\
$\mathrm{C} 3 \mathrm{a}$ & 19.20 & 0.90 & 3450 & 3.12 \\
$\mathrm{C} 3 \mathrm{~b}$ & 18.60 & 0.90 & 3550 & 3.15 \\
$\mathrm{C} 3 \mathrm{c}$ & 19.10 & 1.00 & 3650 & 3.12 \\
$\mathrm{C} 3 \mathrm{c}$ & 18.20 & 0.80 & 3700 & 3.11 \\
\hline
\end{tabular}

It is found that BFS has harder structure than BOF slag and hardly ground slag. BFS of $2400-2500 \mathrm{~cm}^{2} / \mathrm{g}$ reaches the required fineness after 4 hours of grinding when BOF slag takes only 3 hours for this degree of fineness. The reference cement (C) produced as Portland cement has a softer structure than the rest of specimens. Thus, it can easily be said that BFS and BOF slag, ground separately, can attain the same granule size on the condition that they are ground finely. When cement's specific gravity results are examined, it is found that waste materials (BFS and BOF slag) substituted with clinker have lower specific gravity values.

Volume expansion values of cements are found to be within the limits set by Turkish Standards (TS-EN 196-3 2002). The outcomes observed that the expansion of cements with BOF slag additive is higher than that of other cements. In BOF slag, when the volume is stable, the rate of free $\mathrm{CaO}$ and $\mathrm{MgO}$ is of great importance since the reaction between both oxides and water has an effect on volume stability as motioned by Altun and Yilmaz (2002). 


\subsection{Alkali silica reaction}

Mortar specimens are exposed to $1 \mathrm{~N} \mathrm{NaOH}$ solution with a temperature of $80^{\circ} \mathrm{C}$ for 14 days. The expansions of the mortar specimens exposed to $\mathrm{NaOH}$ solution are given in Table 4.

The outcomes showed that the ASR expansion values are lower than $0.2 \%$, except $\mathrm{C} 1 \mathrm{~b}, \mathrm{C} 1 \mathrm{c}, \mathrm{C} 1 \mathrm{~d}$ which is defined as a limit value on ASTM C-1260 (2007). ASR expansion value is increased by the increase of BOF slag percentage in the cement as shown $\mathrm{C} 1$ series sample (see Table 4).

Table 4. Alkali silica reaction expansions of cements

\begin{tabular}{lllll}
\hline & \multicolumn{4}{c}{ ASR Expansion (\%) } \\
\cline { 2 - 5 } & 2 day & 6 day & 10 day & 14 day \\
\hline C & 0.096 & 0.146 & 0.176 & 0.184 \\
C1a & 0.094 & 0.137 & 0.169 & 0.186 \\
C1b & 0.096 & 0.149 & 0.187 & 0.208 \\
C1c & 0.110 & 0.163 & 0.182 & 0.222 \\
C1d & 0.114 & 0.169 & 0.192 & 0.212 \\
C2a & 0.040 & 0.066 & 0.086 & 0.107 \\
C2b & 0.034 & 0.056 & 0.080 & 0.104 \\
C2c & 0.032 & 0.052 & 0.080 & 0.097 \\
C2d & 0.032 & 0.061 & 0.075 & 0.100 \\
C3a & 0.083 & 0.123 & 0.154 & 0.170 \\
C3b & 0.089 & 0.112 & 0.143 & 0.160 \\
C3c & 0.098 & 0.125 & 0.136 & 0.160 \\
C3d & 0.109 & 0.134 & 0.156 & 0.170 \\
\hline
\end{tabular}

However, the increase of BFS percentage in the cement resulted a decrease in ASR expansion value. The expansions of the BOF slag mortar specimens exposed to $\mathrm{NaOH}$ solution are given in Fig. 2.

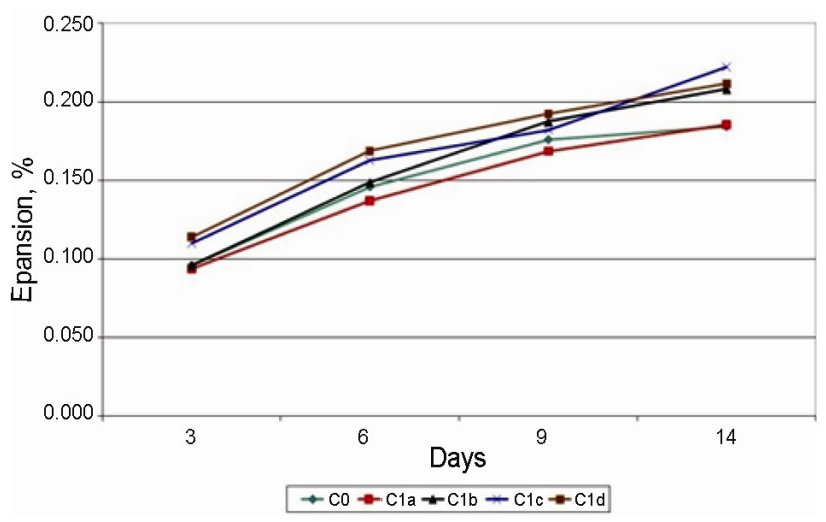

Fig. 2. ASR expansion of BOF slag

When $\mathrm{Cl}$ series ASR expansion value is investigated, the ASR expansion values found to be over than reference series. The reason for the high ASR expansion value is thought to be the ratio of $\mathrm{CaO}$ an $\mathrm{MgO}$ in $\mathrm{BOF}$. BOF slag volumetric stability and leaching behavior caused the most concerns. The most important criterion is the volume stability, in which free $\mathrm{CaO}$ and $\mathrm{MgO}$ contents of the slag has an important role. The expansions of the BFS mortar specimens exposed to $\mathrm{NaOH}$ solution are given in Fig. 3.

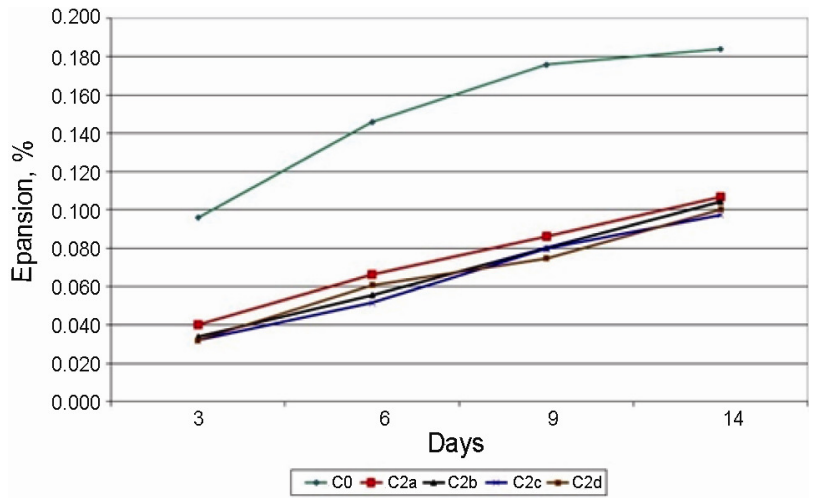

Fig. 3. ASR expansion of BFS

ASR expansion value is also below the limit value given by ASTM-C 1260 (2007). It is known that the existence of BFS reduced the ASR expansion value. Since pozzolan are less reactive and the reaction results include less amount of alkali than the Portland cement, they are addressed as solvent. The pozzolan decreases the amount of $\mathrm{Ca}(\mathrm{OH})_{2}$, which decrease the $\mathrm{PH}$ value, therefore the amount of alkali also reduces. The expansions of the BOF slag and BFS mortar specimens exposed to $\mathrm{NaOH}$ solution are given in Fig. 4.

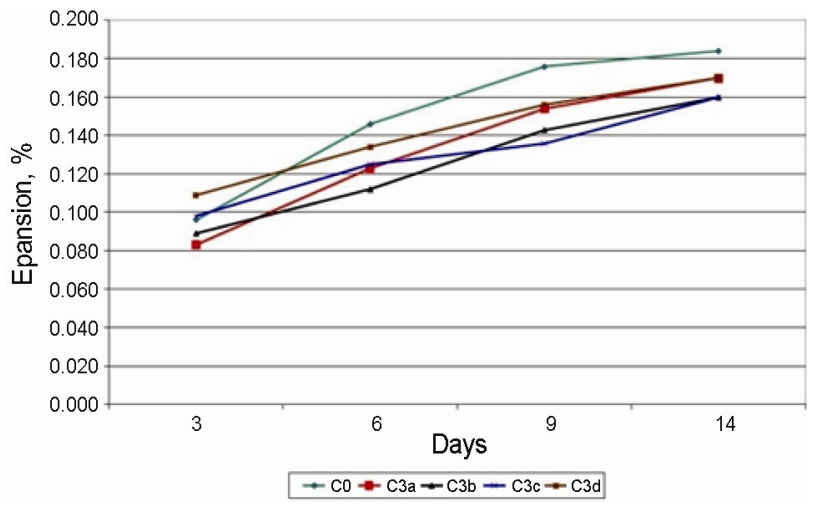

Fig. 4. ASR expansion of BOF slag and BFS

C3 Series resulted that existence of BFS eliminates the result of harmful effects of BOF slag. Also the ASR expansion values of $\mathrm{C} 3$ series are below the limit value of ASTM C-1260 (2007). ASR is the attack of alkali hydroxide to convert the surface layer of the aggregate to alkali silicate. The reaction of pore solution with $\mathrm{Ca}(\mathrm{OH})_{2}$ induces gradual dissolution of $\mathrm{Ca}^{2+}$ ions. This is because the concentration of $\mathrm{Ca}^{2+}$ ions is inversely proportional to the square of $\mathrm{OH}^{-}$concentration within the pore solution (Ichikawa, Miura 2007).

Although the pozzolan prevent unfavorable volume expansions through forming C-S-H by reacting with $\mathrm{Ca}(\mathrm{OH})_{2}$, they cannot prevent the volume expansion within the $\mathrm{BOF}$ slag due to the presence of free $\mathrm{CaO}$ and $\mathrm{MgO}$ of $\mathrm{Cl}$ series. However, the existence of BOF slag has positive effects on durability properties of cement (Özkan 2006, 2008; Altun, Y1lmaz 2002). It is generally known from the literature that the carks form within the cement when subjected to temperatures above $400{ }^{\circ} \mathrm{C}$. At $530{ }^{\circ} \mathrm{C}$ the $\mathrm{C}-\mathrm{S}-\mathrm{H}$ gel within the cement start decompos- 
ing. However with the samples containing BOF slag or BFS cement, both cracking and decomposition occur at much higher temperatures (Özkan 2006).

When cement-based materials are exposed to sodium sulphate attack, gypsum and ettringite are produced which can cause expansion in concrete. Formation of gypsum plays an important role in the damage of the material. Gypsum results in softening of the material. There is a good relation between the $\mathrm{Ca}(\mathrm{OH})_{2}$ content and gypsum formation (Lee et al. 2005). Ettringite formation results in cracking and expansion of the material. Expansion is related to the water absorption of crystalline ettringite. The presence of a BOF slag results in an increase in the resistance to sodium sulphate attack (Özkan 2008).

\subsection{Microstructure examination}

$\mathrm{X}$-ray powder diffraction (XRD) is a direct method for qualitative and quantative characterization of materials. Each phase produces a unique diffraction pattern independent of others, with the intensity of each pattern proportional to that phases concentration in a mixture. Scanning electron microscopy (SEM) high resolution images of the surface of samples with magnification of up to $100,000 x$ show the structure of the mortar. SEM/EDX allows elemental analysis of samples and is used for characterisation of morphologies and textural and compositional interrelationships of mortar components. XRD allows analysis of crystalline materials including binder phases; belite and alite; and crystallised alteration products (Lamond, Pielert 2006).

In this work the usability with incorporation BOF slag and BFS in cement production has been investigated. SEM micrographs of mortar bars produced from different cement combinations were taken at 500x (a) and 2000x (b) magnifications. XRD analysis was then performed on the samples. The SEM and XRD analysis were performed on the samples denoted as $\mathrm{C}, \mathrm{C} 1 \mathrm{~b}, \mathrm{C} 2 \mathrm{~b}$ and $\mathrm{C} 3 \mathrm{~b}$. The results of the reference sample $\mathrm{C}$ are presented in Fig. 5.
The reference sample $\mathrm{C}$ consists of pure clinkerGypsum mixture. According to XRD results (Fig. 5) the level of $\mathrm{Fe}, \mathrm{FeO}$ and $\mathrm{MgO}$ are acceptable levels on the bases of TS-EN 196. SEM images show that Calcium Hydrate fibers were formed in the vicinity of cement gel. In addition, etringite and flake-like calcium hydropoxide crystals developed in the microstructure.

Microstructure analysis of $\mathrm{Clb}$ samples in which BOF slag replaced clinker is presented in Fig. 6.

$\mathrm{C} 1 \mathrm{~b}$ is a cement obtained by substituting $40 \%$ of clinker-gypsum with BOF. XRD analysis indicates that the $\mathrm{C} 1 \mathrm{~b}$ sample is characterized particularly by the presence of $\mathrm{Al}$ in addition to $\mathrm{Fe}, \mathrm{FeO}, \mathrm{Mg}$ minerals. Although the separated BOF slag is used, XRD analysis showed that there is still considerable amount of Fe minerals in the microstructure. The fact that there are high amounts of $\mathrm{Al}$ and $\mathrm{MgO}$ minerals in the microstructure, increases the volume of ASR expansion. The SEM image showing the presence of cracks in the C-S-H gel (Fig. 6) is strong evidence of this claim.

C2b sample is a kind of cement obtained by substituting $40 \%$ BFS with clinker. XRD analysis and SEM micrographs for $\mathrm{C} 2 \mathrm{~b}$ type cement are given in Fig. 7.

XRD analysis indicates that the amount of $\mathrm{Fe}, \mathrm{Mg}$ and $\mathrm{Al}$ elements within $\mathrm{C} 2 \mathrm{~b}$ are lower than that of $\mathrm{C} 1 \mathrm{~b}$ sample. However the amount of $\mathrm{Ca}$ and $\mathrm{CaO}$ in $\mathrm{C} 2 \mathrm{~b}$ is much higher. SEM micrographs show the presence of $\mathrm{C}-\mathrm{S}-\mathrm{H}$ gel with little amount etringite around their peripheral regions. C-S-H gel is formed by the reaction between pozzolan and $\mathrm{Ca}(\mathrm{OH})_{2}$. It has been reported that the presence of C-S-H within the matrix increases durability of the material against sodium sulphates (El Sokkary et al. 2004; Lee et al. 2005; Aye, Oguchi 2011). It has been observed in the current study that the presence of C-S-H gel also increases durability of the material against ASR.

C3b sample obtained by substituting $20 \%$ BFS and $20 \%$ BOF slag with klinker. XRD analysis and SEM micrographs for $\mathrm{C} 3 \mathrm{~b}$ type cement are given in Fig. 8.

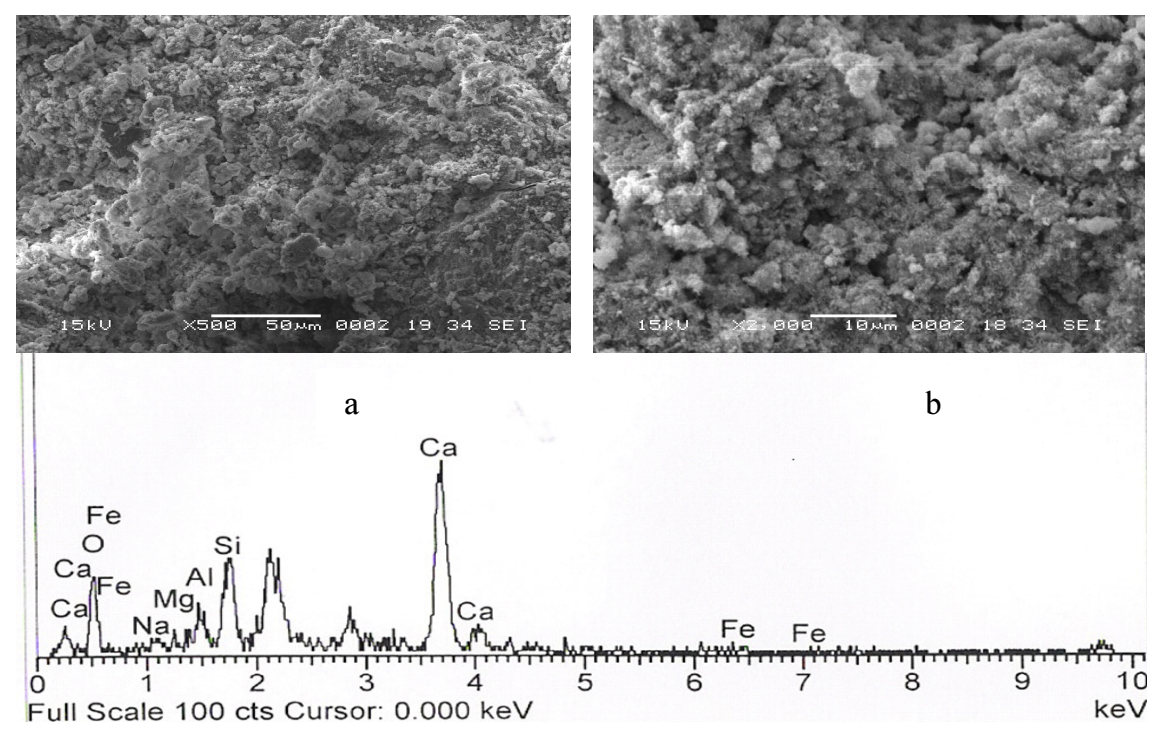

Fig. 5. XRD vet SEM analysis of "C" 


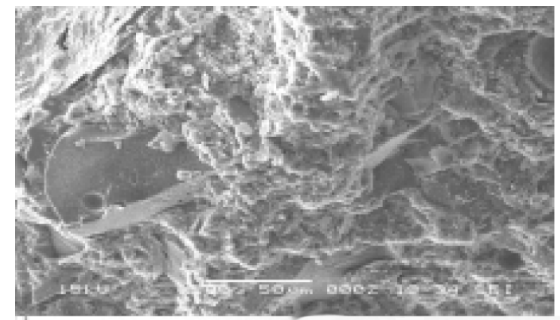

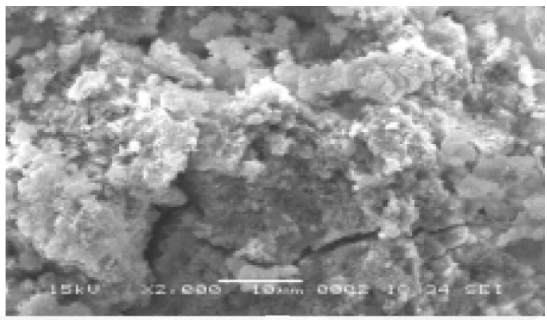

b

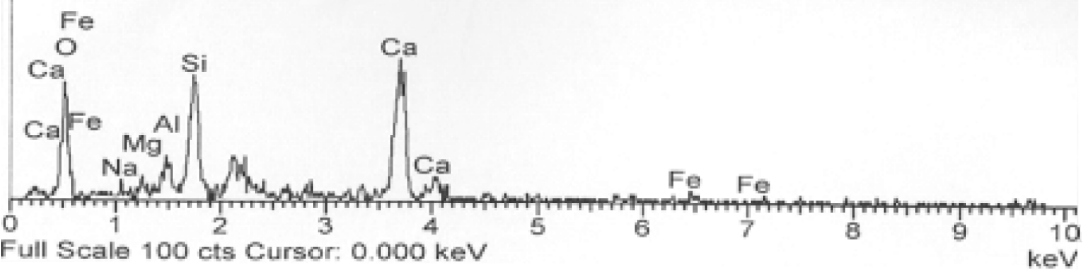

Fig. 6. XRD and SEM analysis of "C1b"

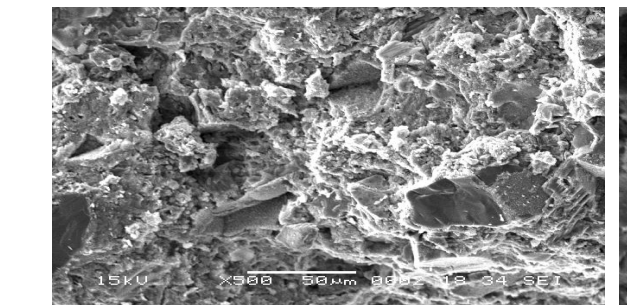

a

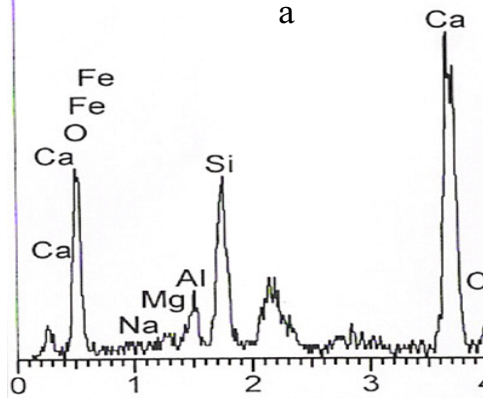

Full Scale 100 cts Cursor: $0.000 \mathrm{keV}$

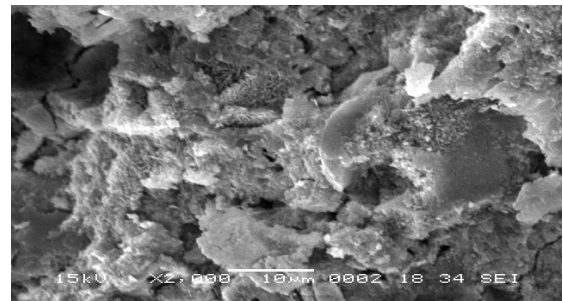

b

Fig. 7. XRD and SEM analysis of "C2b"
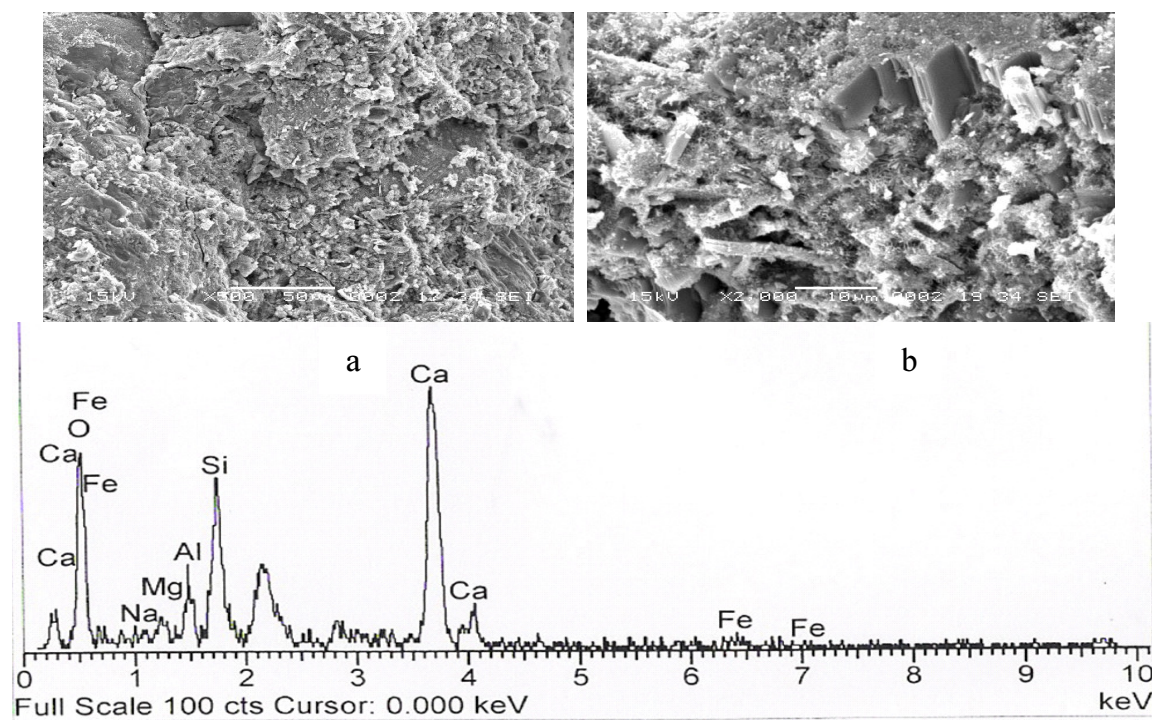

Fig. 8. XRD and SEM analysis of "C $3 b$ " 
$\mathrm{XRD}$ analyses show that in $\mathrm{C} 3 \mathrm{~b}$, the amount of $\mathrm{FeO}$ and $\mathrm{Ca}$ elements are lower than that of $\mathrm{C} 2 \mathrm{~b}$ compared to that of $\mathrm{Ca}$ minerals despite not being as much as $\mathrm{Ca}$ minerals. SEM images prove the formation of C-S-H gel with etringite in $\mathrm{C} 3 \mathrm{~b}$ samples. The cracks and expansions observed within $\mathrm{Clb}$ are found to be reduced in the $\mathrm{C} 3 \mathrm{~b}$ samples. This reduction can be attributed to the use of $\mathrm{BFS}$ in C3b samples instead of BOF slag.

\section{Conclusions}

BOF slag, which is considered as a non-environmentally friendly material and has storage difficulties, has $65 \%$ usage in Europe, but none in Turkey. That it is really very important step to use of BOF slag in other industries for sustainability point of view. Cement production can a new production line for BOF slag. This study shows that using BOF slag increase ASR expansion value of cement, which is harmful. But it has also has positive effects on the other durability properties of cement. In order to eliminate the harmful effects of BOF slag, other materials such as BFS can also be used in cement production. The formation of cracks and expansion in samples with BOF has been reduced approximately by $20 \%$ in the BFS added samples. Durability properties of cement are at the required level when BOF slag and BFS are used together. Using environmentally damaged BOF slag along with the other waste material, BFS, in production of cement material is very important in use of waste materials.

\section{Acknowledgement}

This article supported from Sakarya University, grant number is 2010-05-08-004.

\section{References}

Altun, I. A.; Y1lmaz, I. 2002. Study on steel furnace slag with high $\mathrm{MgO}$ as additive in Portland cement, Cement and Concrete Research 32(8): 1247-1249.

http://dx.doi.org/10.1016/S0008-8846(02)00763-9

ASTM C-1260 Standard test method for potential alkali reactivity of aggregates (mortar-bar method). American Society for Testing and Materials (ASTM), 2007. 10 p.

Aye, T.; Oguchi, C. T. 2011. Resistance of plain and blended cement mortars exposed to severe sulfate attacks, Construction and Building Materials 25(6): 2988-2996. http://dx.doi.org/10.1016/j.conbuildmat.2010.11.106

Binici, H.; Temiz, H; Köse, M. M. 2007. The effect of fineness on the properties of the blended cements incorporating ground granulated blast furnace slag and ground basaltic pumice, Construction and Building Materials 21(5): 1122-1128.

http://dx.doi.org/10.1016/j.conbuildmat.2005.11.005

Chatterji, S. 2005. Chemistry of alkali-silica reaction and testing of aggregates, Cement and Concrete Composites 27(7-8): 788-795.

http://dx.doi.org/10.1016/j.cemconcomp.2005.03.005

El Sokkary, T. M.; Assal, H. H.; Kandeel, A. M. 2004. Effect of silica fume or granulated slag on sulphate attack of ordinary portland and alumina cement blend, Ceramics International 30(2): 133-138.

http://dx.doi.org/10.1016/S0272-8842(03)00025-7
Escalante-Garcia, J. I.; Espinoza-Perez, L. J.; Gorokhovsky, A.; Gomez-Zamorano, L. Y. 2009. Coarse blast furnace slag as a cementitious material, comparative study as a partial replacement of Portland cement and as an alkali activated cement, Construction and Building Materials 23(7): 2511-2517.

http://dx.doi.org/10.1016/j.conbuildmat.2009.02.002

Garcia-Diaz, E.; Riche, J.; Bulteel, D.; Vernet, C. 2006. Mechanism of damage for the alkali-silica reaction, Cement and Concrete Research 36(2): 395-400.

http://dx.doi.org/10.1016/j.cemconres.2005.06.003

Ichikawa, T.; Miura, M. 2007. Modified model of alkali-silica reaction, Cement and Concrete Research 37(9): 12911297. http://dx.doi.org/10.1016/j.cemconres.2007.06.008

Ichikawa, T. 2009. Alkali-silica reaction, pessimum effects and pozzolanic effect, Cement and Concrete Research 39(8): 716-726. http://dx.doi.org/10.1016/j.cemconres.2009.06.004

Lamond, J. F.; Pielert, J. H. (Eds.). 2006. Significance of tests and properties of concrete and concrete-making materials. ASTM International. $664 \mathrm{p}$. http://dx.doi.org/10.1520/STP169D-EB

Lee, S. T.; Moon, H. Y.; Swamy, R. N. 2005. Sulfate attack and role of silica fume in resisting strength loss, Cement and Concrete Composites 27(1): 65-76. http://dx.doi.org/10.1016/j.cemconcomp.2003.11.003

Özkan, Ö. 2006. Heat effects on cements producing with GBFS and SS as additives, Journal of Materials Science 41(21): 7130-7140. http://dx.doi.org/10.1007/s10853-006-0930-x

Özkan, Ö. 2008. Sulfate resistance of mortars produced with granulated blast furnace and steel slag additive cements, Journal of Gazi Universiy Architecture and Engineering Faculty 23(1): 1-8.

Pan, J. R.; Huang, C.; Kuo, J.-J.; Lin, S.-H. 2008. Recycling MSWI bottom and fly ash as raw materials for Portland cement, Waste Management 28(7): 1113-1118. http://dx.doi.org/10.1016/j.wasman.2007.04.009

Puertas, F.; García-Díaz; I.; Palacios, M.; Gazulla, M. F.; Gómez, M. P.; Orduña, M. 2010. Clinkers and cements obtained from raw mix containing ceramic waste as a raw material. Characterization, hydration and leaching studies, Cement and Concrete Composites 32(3): 175-186. http://dx.doi.org/10.1016/j.cemconcomp.2009.11.011

Reddy, A. S.; Pradhan, R. K.; Chandra, S. 2006. Utilization of Basic Oxygen Furnace (BOF) slag in the production of a hydraulic cement binder, International Journal of Mineral Processing 79(2): 98-105. http://dx.doi.org/10.1016/j.minpro.2006.01.001

Shi, C.; Qian, J. 2000. High performance cementing materials from industrial slags - a review, Resources, Conservation and Recycling 29(3): 195-207. http://dx.doi.org/10.1016/S0921-3449(99)00060-9

Shih, P.-H.; Chang J.-E.; Chiang, L.-C. 2003. Replacement of raw mix in cement production by municipal solid waste incineration ash, Cement and Concrete Research 33(11): 1831-1836. http://dx.doi.org/10.1016/S0008-8846(03)00206-0

Shih, P. H.; Wu, Z. Z.; Chiang, H. L. 2004. Characteristics of bricks made from waste steel slag, Waste Management 24(10): 1043-1047. http://dx.doi.org/10.1016/j.wasman.2004.08.006

TS-EN 196-1 Methods of testing cement - Part 1: determination of strength. Turkish Standards Institute, Ankara, 2009. 36 p. (in Turkish). 
TS-EN 196-3 Methods of testing cement - Part 3: determination of setting time and soundness. Turkish Standards Institute, Ankara, 2002. 6 p. (in Turkish).

TS-EN 196-6 Methods of testing cement - Part 6: determination of fineness. Turkish Standards Institute, Ankara, 2000. 34 p. (in Turkish).
Yüksel, I.; Bilir, T.; Özkan, Ö. 2007. Durability of concrete incorporating non-ground blast furnace slag and bottom ash as fine aggregate, Building and Environment 42(7): 2651-2659.

http://dx.doi.org/10.1016/j.buildenv.2006.07.003

Ömer ÖZKAN. Assoc. Prof., Dr in the Technology Faculty, Civil Engineering Department at Sakarya University, Turkey. His research interests include the construction materials, particularly wastes.

Mehmet SARIBIYIK. Assoc. Prof., Dr in the Technology Faculty, Civil Engineering Department at Sakarya University, Turkey. His research interests include materials and construction materials, particularly fiber reinforced polymer matrix and glass fiber reinforced polymer matrix. 